\title{
Global Civil Society Is Not Utopian, But Feasible: The World After the COVID-19 Pandemic
}

\author{
Junyuan Peng ${ }^{1}, \&$ Jing Shi ${ }^{1}$ \\ ${ }^{1}$ Guangdong University of Foreign Studies, Guangdong, Guangzhou, Guangdong, P.R. China \\ Correspondence: Jing Shi. E-mail: sj@ oamail.gdufs.edu.cn
}

Received: August 21, 2020

Accepted: September 9, 2020

Online Published: September 24, 2020

doi:10.5539/ass.v16n10p47

URL: https://doi.org/10.5539/ass.v16n10p47

\begin{abstract}
At the beginning of 2020, the COVID-19 Pandemic has swept the world, which raises the awareness of global governance and global civil society. This paper attempts to prove global civil society is feasible and analyses its main functions during the period of resistance of the COVID-19 Pandemic. The paper unfolds in four parts. The First part is a brief introduction to the question this paper tends to address after the COVID-19 Pandemic. After that, it is the definition of civil society. Civil society can be defined as a complementary arena for state and market to ensure common welfare and public good through non-violent, voluntary and bottom-up process. However, this definition encompasses different connotations with the passage of time. In the third part, it states that civil society is inevitably globalized in the challenge of globalization. Quite a number of problems go beyond borders and the reaches of states, which leaves a vacuum for a corresponding force to regulate them. Also, global social movement-the main actor of global civil society, as an important agent, ensures the economy liberalism-embedded transnational economic organizations, as the main structure of global governance, accountable. In addition, the development of convenient communication and value convergence provide the objective conditions for the emergence of global civil society. Global civil society makes transnational organizations accountable, solves problems beyond state borders and ensures the public good and welfare. In a nutshell, global civil society is an indispensable part of today's global governance.
\end{abstract}

Keywords: global civil society, global governance, COVID-19

\section{Introduction}

Civil Society is a terminology, which emerged in the late seventeenth and eighteenth centuries as the result of crisis in social order and a breakdown of existing paradigms of the idea of order (Seligman, 1992). With the advent of globalization, our ontology cannot be imprisoned by state-centric ideology, a multi-layered governance comes into being. As an indispensable part of governance, civil society (with the major actor-social movement), grabs people's attention. However, there is suspicion about the feasibility of global civil society, which is contrary to this paper's point of view. Globalization supplies global civil society, theoretical reasons and objective conditions to exist as a normative concept. In practice, the functions of global civil society give itself the factual connotation.

The COVID-19 outbreak has rapidly evolved into a global public health crisis, not only produced a huge threat to human life safety and body health, and economic globalization has been hit, the omni-directional chain influences many areas worldwide, highlights the urgency and the importance of global governance. However, the existing global governance system has been slow to respond to the epidemic, with some failures and limited effectiveness. The response of international organizations, institutions and mechanisms is inadequate and ineffective. Leadership and coordination and cooperation among major countries have become more difficult, failing to reflect the role of leadership. Countries need to rethink how they can strengthen the reform of the global governance system to better ensure human public health security. In short, global governance remains a long and arduous task, so the global civil society is vital.

\section{Definition of Civil Society}

\subsection{Historical Origin}

Civil society has its roots deep in history. In the late eighteenth century, bourgeois society was in need of a tool to defend its new-born interests in the feudal society which is thought to be the very origin of civil society. This 
historical experience buttresses the notion that capitalism gives rise to civil society (Howell, 2001). In this European context, 'civil society and bourgeois were synonymous' (Cox, 1999). During this period, Adam Smith's 'invisible hand' and Hegel's 'ruse of reason' endowed civil society with commercial connotation. Civil society was thought to be a 'commercial' society in which violence was contained and peace and fair trade were ensured (Deakin, 2001). At the same time, Marx held a different, class conflict-based point of view: civil society held the seed of its own demise as in this realm the proletariat would finally take the place of bourgeoisie (Cox, 1999). In the nineteenth century, with the proliferation of association outside state power, civil society was no longer treated as a tool to defend the ruling class's interests, which were mostly economic. Civil society became an alternative to check the ruling class's rights while protecting the vulnerable in society. Although Hegel distinguished the three spheres of family, society, and the state, he emphasized civil society's economic connotation (its connection with the bourgeoisie) and it was only in the twentieth century that civil society and the economy came to be conceptually distinguished as two autonomous realms (Howell, 2001). In the twentieth century, the tripartite model-state, market and civil society was founded. Nowadays, the global civil society promotes the global governance in all directions. For a global public health crisis like the COVID-19 pandemic, the only way forward is for the world to form a global community of human health and work together to deal with it. The prevention and control process of this epidemic also shows that no country can become an island of self-isolation, and mankind may go through similar tests in the future, which means that we need to be united as global civil society to handle the global issue. Civil society also plays an important on politics and global governance not just on financial coverage.

Historical experiences underpin the truth that connotation of civil society cannot be frozen in a certain historical period, instead, it is flexible enough to adapt to changing times.

\subsection{Characteristics of Civil Society}

In this paper, civil society is defined as a spontaneous, intermediate complementary realm between state and market, among which there is a major actor-social movement to check the activities of both state and market and ensure public good through non-violent, bottom-up, voluntary and various means.

The first characteristic of civil society is spontaneity. Civil society is a realm, which takes time to be cultivated and is not brought into existence and organized in accordance with an agenda. It takes shape in compliance with the passage of time automatically (Deakin, 2001). The second characteristic is its complementary function. Civil society serves as a complementary and intermediary realm for market and state, rather than replacing them. It is a realm in which to let every voice can be heard in order to constrain and check the unreined state and market forces, alleviate inequalities and ensure public good (Howell, 2001). The third characteristic is civility. Civility here has a double meaning: "it consists of non-governmental institutions (or "civilian") that tend to have non-violent (or "civil") effect' (Keane, 2003). Last but not least, the main characteristic of civil society it is necessary to mention here, is the variety of social movement.

There has always been a misconception that civil society is a common community. However, in civil society, there are various types of institutions whose goals and purposes are different and there are people from different backgrounds and cultures, with different beliefs and purposes. The diversity in civil society is much more dazzling than people imagine. But this does not imply that civil society goes to another extreme and these actors in it are in a mess. People and institutions in civil society share the same goal in that they are generally intend to ensure public good, from different points of view and in different ways.

\subsection{Major Actor in Civil Society}

The major actor in civil society is social movement, which contributes to the formation of civil society. Social movement can be defined as 'ongoing collective efforts to bring about consequential social change' (McCarthy, 1997). An earlier model developed by Wilson, categorizes social movements as follows: Transformative movements which intend to change society fundamentally mostly by means of violence; reformative movements that seek to remove current injustice and inequality by partial changes; redemptive movements which seek to develop another sustainable way of living and ideology against materialism (Cohen et al., 2002 ). However, no one social movement can be pigeonholed exactly into one category because of the changing nature of social movement (Cohen et al., 2002).

As mentioned above, we attempt to define civil society from its historical origins, characteristics and main actor. At present, globalization becomes an element in the definition of civil society, hence global civil society. Global civil society is 'a transnational domain in which people form relationships and develop elements of identity outside their role as a citizen of a particular state' (Wapner, 2000). This definition implies the cross-border, transnational connotations of global civil society. 'It represents a sphere that thus transcends the self-regarding 
character of the state system and can work in the service of a genuinely transnational, public interest' (Wapner, 2000). Global civil society is "the worldwide spread around for common human happiness" (Lester, 2007).

\section{Global Civil Society-a Utopian Concept?}

\subsection{Reasons for Emergence of Global Civil Society}

Globalization changes today's ontology and paradigm. Ontology is a static way of thinking which identifies the important elements consisting of the existing world, while paradigm is the changes as well as the stabilities, which maintain the important elements (Rosenau, 1999). In today's ontology, the globalized world needs global governance, within which the state is no longer the sole and only agent. Civil society becomes an indispensable agent in it. In paradigm, civil society and its behavior-social movement have been globalized due to the requirement by globalization to maintain their existence.

First, increasingly worried experts in world politics find that there is an uneasy imbalance between globalized structure of power and representation of accountability, which remains within state borders (Williams, 2000). Quite a number of problems go beyond borders, but transnational organizations are still in their infancy in term of dealing with these problems, bringing a vacuum of factors, such as environmental problems caused by footloose Transnational Corporations (TNCs). Under these circumstances, global civil society seems to be a must for solving these problems. TNCs' economic ability exceeds that of many countries. For instance, General Motor's annual sales exceed the Gross Domestic Product (GDP) of Indonesia; International Business Machine (IBM) exceeds combined GDP of Chile, Costa Rica and Ecuador (UNRISD, 1995). To some extent, TNCs' gigantic economic power enables them to have more say than nation states. Without effective control, the environment has been heavily contaminated by industry, driven by the illusion of limitless growth, among which, mostly, TNCs (Falk, 1987). 'Code of conduct' only helps to obscure TNCs' role in causing environmental degradation (Newell, 2000); and conventional transnational economic organizations in which liberalism is orthodoxy, will only leads to a brutally competitive marketplace without any regard to environmental protection (Lynch, 2000). The accountability of transnational economic organizations is open to question. Global social movement, as an agent, has the obligation to conduct a bottom-up action to make the top-down structure, the transnational economic organizations, more accountable. With the challenges of the COVID-19, the international community must set up the ideas of human destiny community, form the concept system of community, policy community, community responsibility and community action, only in this way can abandon the zero-sum thinking, abandon the old idea, eliminate the narrow nationalism and racism, strengthening coordination and cooperation, share the wind and rain, forming a community of real human destiny, together to protect human life security and the development and prosperity (Song, 2020). The fragmentation of governance system is the result of the power competition of sovereign states in global governance, not the inevitable consequence of the governance path of global civil society. The economic and security fields themselves involve the core interests of sovereign states to the greatest extent. Meanwhile, different countries have different preferences in participating in global governance, especially between developed and developing countries. Therefore, countries will compete for the dominance of the governance mechanism and tend to establish a governance mechanism in line with their own interests (James, 1995). The increase of global problems makes the theory and practices of international cooperation between state actors plagued with the challenges of the globalization era. Global civil society that emerged in this context, in terms of cooperation main, the level of cooperation, the form and concept of cooperation, adapts and reflects the new concept of international cooperation in the era of globalization, including development needs of diversification power and value, and rights democratization (Song et al., 2013). The phenomenon of "anti-globalization" caused by the epidemic will encourage people to think better about how to make up for the shortcomings of globalization, which will provide new opportunities for reshaping the global governance system. First, the new global governance system should follow the vision of building a community with a Shared future for mankind. The epidemic poses a serious threat to human health and the world economy. It demonstrates the degree to which globalization has made countries interdependent and closely linked. It has made more and more people realize that no country is an "island" and the necessity to build a community with a Shared future for mankind. In March 2017, the UN Security Council unanimously adopted resolution 2344, which included for the first time the concept of "building a community with a Shared future for mankind". This means that the international community has reached consensus on the concept of building a community with a Shared future for mankind as the guiding concept for reshaping the global governance system. In the face of global systemic risks such as environmental pollution and epidemic diseases, countries need to pool their willingness to work together to form a strong synergy. Only when a sense of wholeness is established can countries have a sense of cooperation and solidarity God, will be in front of the problem of joint responsibility, joint response, forming a joint force from the global epidemic prevention and control process. Any country that 
lacks this sense of community will face more problems in its response to the epidemic (Sun, 2020). During the outbreak, stressed that no country, including the United States, can defeat the virus on its own, and that the current situation requires a global vision and action (Henry, 2020). The world must foster a sense of community with a Shared future for mankind and form a community of ideas.

\subsection{Global Integration}

Global integration provides objective conditions for the emergence of global civil society. First and foremost, with economic global development, increasing material surplus allows people to have more time and resources, and should enable them to get their voices heard (Kriesberg, 1999). Secondly, improving communication technology facilitates the networking of groups in global civil society and participation in collective decision-making (O'Brien et al., 2000; Kriesberg, 1997). Information technology shortens the distance among civil societies in different countries, enabling civil societies to have more connections, which makes global civil society possible. Comparatively cheap but faster means of transportation allow more mobilization in global civil society. Thirdly, values and norms are converged and diffused among people from different parts of the world and different culture backgrounds. Although there are some counter-forces challenging value convergence, but in the long-term, trends in the world move people towards shared values. The acceptance of basic human rights narrows the differences among people and underscores people's desire for a more democratic and just world. On the other hand, the dissemination of the common values gives people a chance to compare what they have and what is ideal, which is a good way of arousing their interest in participation in public life, in order to change their current situation (Kriesberg, 1997). Since the beginning of the 21st century, global governance has been faced with a democratic crisis and a "democratic deficit". Most global governance institutions have designed certain mechanisms to participate in civil society initiatives and enhance information communication with the public in order to directly face the public ( $\mathrm{Li}, 2020)$. Clearly, the problem we meet urge us to build up a united society to integrate our limitless power to fight as a team.

\subsection{Functions of Global Civil Society}

Global civil society functions mainly in the form of its main actor-global social movement. In the national arena, global civil society can exert pressure on domestic policy made by government. For example, 'Amnesty International' sometimes organizes demonstrations at the embassies of a government that abuses human rights in order to press other governments to take action against it' (Smith et al., 1997). At another extreme, global civil society encourages government to adopt a certain policy by demonstrating that other governments will follow suit (Smith et al., 1997). In addition, global social movement does not just work on state government, but also domestic markets. It serves as a watchdog, checking market players' wrongdoings (Howell, 2001), in order to ensure that they live up to their appropriate responsibilities but do not violate any laws or regulations. In the intergovernmental arena, global civil society alleviates the bad effects brought on by liberalism-embedded transnational organizations (Smith et al., 1997). Global civil society can promote the interests and rights of the public good that are outside the structure of transnational economic organizations, and hold them account (Higgott et al., 1999). The existing transnational economic troika-the International Monetary Fund (IMF), the World Bank and the World Trade Organization (WTO) are top-down structures, whose abilities are checked and accountability ensured by global social movements which are 'a system of global governance from the bottom up' (Cox, 1997). Global social movement attempts to influence the policy-making process by exerting pressure on the existing structure. For example, global social movement engages with the IMF by urging a fundamental reform in it (O'Brien et al., 2002); it attempts to prevent projects funded by the World Bank that are ecologically degrading, by means of confrontation and cooperation (Williams, 2000); in the WTO, holders of power remain close to social movements and take their opinions into account during policy-making processes (Williams, 2000). In the transnational arena, global civil society serves as a TNC monitor, seeking to 'deter them from violating their legal and perceived social obligations by threatening exposure and the activation of campaigns against them' (Newell, 2002).

In the face of the COVID -19 pandemic, studies show that global civil society is a builder of global governance mechanisms. On one hand, global civil society makes it easy to contact with other organizations, thus forming cooperation networks among organizations in different fields. Through timely, frequent and effective information communication and exchange, the possibility of reaching consensus on issues is enhanced, and the institutional and institutional bonding of each organization is promoted. UNESCO builds professional platforms to share good, science-based information in a timely manner can improve the efficiency and quality of decision making in response to the epidemic. "Using words and images to promote the free exchange of ideas" is one of UNESCO's specific tasks. It has created a "Resource Center of Responses to COVID-19" to address the current crisis by supporting freedom and professional media, enhancing access to information and digital technologies. 
On the other hand, global civil society is subject to fewer rules, procedures and institutions, compared with the existing global governance institutions, it has the advantages of quick decision-making and strong execution, which improves the ability of the global governance mechanism to solve emergencies, and enhances the flexibility and action power of the global governance mechanism $(\mathrm{Li}, 2020)$ For example, in the early days of the COVID-19 outbreak in 2020, many international negotiations acted in a timely manner and made donations to support the prevention and control of the epidemic. During the Chinese Spring Festival, it urgently called on branches around the world and local Chinese groups to purchase medical supplies and epidemic prevention supplies in short supply, and opened new channels within its capacity to support China's epidemic prevention.

Facing global problems, it is urgent for all countries to abandon the zero-sum mentality and the Cold War mentality, transcend differences in ideology and political system, put aside pride and prejudice, and truly view the world as a whole. Only in this way can all countries become partners in global governance, working in solidarity, treating each other as equals, sharing wisdom, learning from each other, and working together to overcome difficulties.

\section{Conclusion}

Civil society, a terminology undergoing the test of time, has grabbed people's attention once again. In this paper, this terminology has been scrutinized from three aspects: historical origins, characteristics and main actor in it. Different historical experiences endow it with different definitions. With the advent of globalization, inevitably, civil society is given a brand-new connotation, this time-global civil society. Some people have doubts about the feasibility of 'global' civil society but I propose that global civil society is not just a normative concept, whose existence is brought about by globalization ontology theoretically, but also that it has objective conditions, which allow it to exist and grow. In addition, the functions of global civil society in global governance bring it its factual significance. To deal with worldwide crisis like the COVID-19, it is needy for a sense of wholeness and unity. Global civil society, being both factual and normative as well, is not a utopian concept, but a feasible one.

With the challenges of global crisis, we human beings should be united and put aside pride and prejudice, truly viewing the world as a whole. We need to uphold the idea of human community with a shared future, update and supplement the current international governance system, create new institutions, and strengthen the coordination and cooperation among major countries. Efforts also need to be made to enforce the empowerment of the worldwide organizations, enhance their authority and action force. Measures should be implemented to establish the global governance system and promote the form of global civil society. With all these efforts, a shared community of ideas, institutions, policies and responsibilities can be better established, which means that global civil society is feasible. Only in this way can all countries jointly meet the global challenges facing human- kind in the future and ensure people's life and health, common development and prosperity.

\section{References}

Cohen, R., \& Rai, S. M. (2002). Global Social Movements: Towards a Cosmopolitan Politics. In R. Cohen, \& S. M. Rai (Eds.), Global Social Movements (pp. 1-17). London: Athlone.

Commission on Global Governance. (1995). Our Global Neighborhood: The Report of the Commission on Global Governance (p. 2). New York: Oxford University Press.

Cox, R. W. (1997). The New Realism: Perspectives on Multilateral and World Order. Basingstoke: Macmillian. Cited in R. Higgott, \& R. Devetak's 'Justice Unbound? Globalization, States and the Transformation of the Social Bond. International Affairs, 75(3), 483-498. https://doi.org/10.1111/1468-2346.00089

Cox, R. W. (1999). Civil Society at the Turn of the Millennium: Prospects for an Alternative World Order. Review of International Studies, 25(1), 3-28. https://doi.org/10.1017/S0260210599000042

Deakin, N. (2001). In Search of Civil Society. New York: Palgrave. https://doi.org/10.1007/978-1-137-10434-2

Erlange, S. (2020, March 22). Another Virus Victim: The U.S. as a Global Leader in a Time of Crisis. The New York Times, p. A4.

Falk, R. (1987). The Global Promise of Social Movements: Explorations at the Edge of Time. Social Transformation and Humane Governance, 12, 173-196. https://doi.org/10.1177/030437548701200202

Higgott, R., \& Devetak, R. (1999). Justice Unbound? Globalization, States and the Transformation of the Social Bond. International Affairs, 75(3), 483-498. https://doi.org/10.1111/1468-2346.00089

Howell, J., \& Pearce, J. (2001). Civil Society and Development: A Critical Exploration. Boulder and London: Lynne Rienner Publishers. 
Keane, J. (2003). Global Civil Society? Cambridge: Cambridge University Press. https://doi.org/10.1017/CBO9780511615023

Kissinger, H. A. (2020, April 3). The Coronavirus Pandemic Will Forever Alter the World Order. Wall Street Journal (Eastern Edition), p. A1.

Kriesberg, L. (1997). Social Movements and Global Transformation. In J. Smith, C. Chatfield, \& R. Pagnucco (Eds.), Transnational Social Movements and Global Politics: Solidarity beyond the State (pp. 3-18). New York: Syracuse University Press.

Li, X. X. (2020). An Analysis of the Role of Global Civil Society in Global Governance-Based on the reflection on the path of 'state-centered' global governance. Legal System and Society, (20), 88-89.

Lynch, C. (2000). Social Movements and the Problem of Globalization. In R. Higgott, \& A. Payne (Eds.), The New Political Economy of Globalization (Vol. II, pp. 149-173). Cheltenham: Edward Elgar Publishing Limited. https://doi.org/10.1177/030437549802300201

McCarthy, J. D. (1997). The Globalization of Social Movement Theory. In J. Smith, C. Chatfield, \& R. Pagnucco (Eds.), Transnational Social Movements and Global Politics: Solidarity beyond the State (pp. 243-259). New York: Syracuse University Press.

Newell, P. (2002). Environmental NGOs and Globalization: The Governance of TNCs. In R. Cohen, \& S. M. Rai, (Eds.), Global Social Movements (pp. 117-133). London: Athlone.

O’Brien, R., Goetz, A. M., Scholte, J. A., \& Williams, M. (2002). Contesting Global Governance: Multinational Economic Institutions and Global Social Movements. Cambridge: Cambridge University Press.

Rosenau, J. (1995). Governance in the Twenty-First Century. Global Governance, 1(1), 4. https://doi.org/10.1163/19426720-001-01-90000004

Rosenau, J. N. (1999). Toward an Ontology for Global Governance. In M. Hewson, \& T. J. Sinclair (Eds.), Approaches to Global Governance Theory (pp. 287-301). Albany: State University of New York.

Salamon, L. M. (2000). Global Civil Society: Dimensions of Non-profit sector (p. 4). Baltimor: EH.

Seligman, A. B. (1992). The Idea of Civil Society. Princeton: Princeton University

Smith, J. (1997). Characteristics of the Modern Transnational Social Movement Sector. In J. Smith, C. Chatfield, \& R. Pagnucco (Eds.), Transnational Social Movements and Global Politics: Solidarity beyond the State (pp. 42-58). New York: Syracuse University Press.

Smith, J., Pagnucco, R., \& Chatfield, C. (1997). Social Movements and World Politics: A Theoretical Framework. In J. Smith, C. Chatfield, \& R. Pagnucco (Eds.), Transnational Social Movements and Global Politics: Solidarity beyond the State (pp. 59-80). New York: Syracuse University Press.

Song, Q. et al. (2013). Global Civil Society and International Cooperation in the Era of Globalization. Journal of Taiyuan Normal University (Social Science Edition), 12(1), 6-9.

Sun, J. S. (2020). The COVID-19 and the Reform of Global Governance. World Economic and Politics, 5, 71-95.

UNRISD. (1995). States of Disarray: The Social Effects of Globalization: An UNRISD Report for the World Summit for Social Development. London: UNRISD.

Wang, L., \& You, L. Y. (2020). UNESCO's Roles, Actions and Challenges in Participating in the Global Governance of COVID-19 Pneumonia Epidemic. International and Comparative Education, 42(8), 3-9.

Wapner, P. (2000). The Normative Promise of Nonstate Actors: A Theoretical Account of Global Civil Society. In P. Wapner, \& L. E. J. Ruiz (Eds.), Principled World Politics: The Challenge of Normative International Relations. Lanham: Rowman \& Littlefield Publishing.

Williams, M. (2000). The World Bank, the World Trade Organization and the Environmental Social Movement. In R. Higgott, G. R. D. Underhill, \& A. Bieler (Eds.), Non-State Actors and Authority in the International System (pp. 241-255). London: Routledge.

\section{Copyrights}

Copyright for this article is retained by the author(s), with first publication rights granted to the journal.

This is an open-access article distributed under the terms and conditions of the Creative Commons Attribution license (http://creativecommons.org/licenses/by/4.0/). 